\title{
Modeling of PV Module Performance under Influence of Surrounding and Essential Factors Variation using Matlab Simulink
}

\author{
Ahmed Mohammed Abed Al-Janabi \\ Baghdad University - Collage of Engineering - \\ Energy Department
}

\author{
Emad Talib Hashim, PhD \\ Baghdad University - Collage of engineering - \\ Energy Department
}

\begin{abstract}
Knowledge of the characteristic of photovoltaic module is a prerequisite for designing and dimensioning a PV power supply. This is the reason for the development of PV module models useful for electrical applications. 7 variables studying model was proposed in this paper as a simple method of modelling and simulation of photovoltaic module using Matlab Simulink. The method is used to determine the characteristic of PV module and studying models successfully reproduce $I_{p_{V}}-V_{p_{V}}$ and $P_{p_{V}}-V_{p_{V}}$ curves and matches real module data under different scenarios of the influence of different values of solar radiation at different temperatures and wind speed into consideration as environment effects and Saturation Current, Ideal Factor, Series and Shunt resistances as a PV module construction variables, the output current and power characteristic of photovoltaic module are simulated using the proposed model.
\end{abstract}

\section{Keywords}

Photovoltaic Module; Modelling and Simulation; Matlab Simulink; Solar Cell.

\section{INTRODUCTION}

Concerning performance studies on PV systems digital simulations, while compared to measurements, are considered faster, low cost and appropriate for sensitivity analysis on different design parameters. The one-diode model is widely used in the literature because it is easier to use than the twodiode model to mathematically model the operation of PV cells and modules take in consideration from [2][5][6][7][9].

The increase in a number of Photovoltaic system installed all over the world brought the need for proper supervision and control algorithms as well as modelling and simulation tool for researcher and practitioners involved in its application is very necessary where made a great transition and form an important part of power generation in this present age. The modelling of PV module generally involves the approximation of the non-linear I-V curve. Many researchers used circuit based approach to characterize the PV module of which the

Simplest model is the current source in parallel to a diode [1][3][4], proposed model shows sharp gradient because the wind speed and atmospheric temperature were kept constant. Hence, In this model take the wind speed in consideration therefore the presented model shows lower cell temperature values because taking the heat transfer causing by wind in consideration.

\section{PV MODULE MATHEMATICAL MODEL}

The PV cell's electrical characteristic under solar irradiance (S) is given in terms of PV cell output current (I) and PV cell voltage (V). Refers to Figure.1 and based on the First law of Kirchhoff, the basic equations which describing electrical characteristics of the PV cell model, can be elaborated through the following

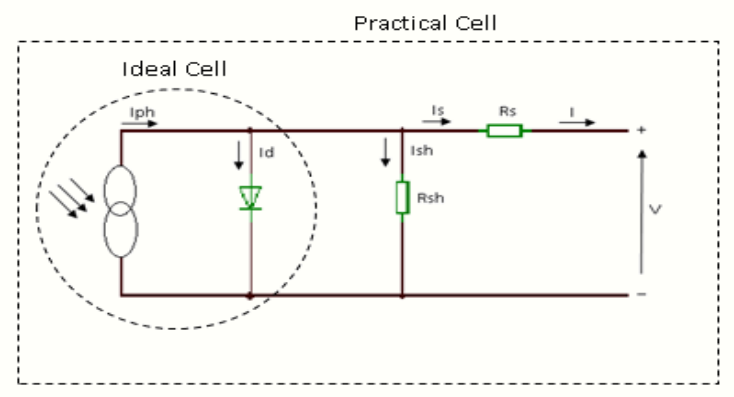

Fig. 1: General Model of PV Cell in a Single Diode Model

The I-V characteristic of a solar cell in practice usually differs to some extent from the ideal characteristic. The solar cell (or circuit) may also contain series $R_{s}$ and parallel (or shunt $R_{s h}$ ) resistances, leading to a characteristic of the form:

$$
\begin{aligned}
I=I_{p h}-I_{d}-I_{s h} & =I_{p h}-I_{s}\left[\exp \left(\frac{q\left(V+I R_{s}\right)}{A k T}\right)-1\right] \\
& -\frac{V+I R_{s}}{R_{s h}}
\end{aligned}
$$

Where $I$ cell output current, $I_{p h}$ light-generated current or photocurrent, $I_{d}$ diode current, $I_{s h}$ current through the shunt resistance.

A PV module is a group of several PV cells which are electrically connected in series and parallel circuits the relationship between the output current and voltage is becomes as follows:

$$
\begin{aligned}
I=N_{p} I_{p h}-N_{p} I_{s}[ & \left.\exp \left(q\left(\frac{V}{N_{s}}+\frac{I R_{s}}{N_{p}}\right) / A k T_{c}\right)-1\right] \\
& -\left(\frac{N_{p} V}{N_{s}}+I R_{s}\right) / R_{s h}
\end{aligned}
$$

The PV module efficiency is insensitive to variation in $R_{s h}$ and the shunt-leakage resistance can be assumed to approach infinity $\left(R_{s h} \rightarrow \infty\right)$ without leakage current to 
ground. The simplified model of PV solar module with suitable complexity can be expressed as Equation (3).

$I=N_{p} I_{p h}-N_{p} I_{s}\left[\exp \left(\frac{q\left(V+I R_{s m}\right)}{N_{s} A k T}\right)-1\right]$

\section{PV MODULE TEMPERATURE DETERMINATION IN RESPECT TO WIND SPEED EFFECT}

In this paper using non - steady state approach parameters affecting the changing of the module temperatures are considered to be time dependent. Therefore, this approach is more realistic, considering the nature of a PV system and could give a more precise prediction of the changing at operating PV module Temperatures over a time period, especially if there is a rapid fluctuation of solar irradiance within a short period of time intervals. This technique is based on the concept that the operating temperature of a PV module is determined by an energy balance. The solar energy that is absorbed by a module is converted partly into thermal energy and partly into electrical energy, which is removed from the cell through the external circuit.

To overcome the problem of the heat transfer whereas the influence of wind induced heat transfer is the main point, [8] proposes a similar simple but wind depending expression of $T_{c}$ :

$$
T_{c}=T_{a}+\left(0.32 /\left(8.91+2 v_{f}\right)\right) G \quad ; v_{f}>0
$$

Where $v_{f}$ in $m / s, \mathrm{G}$ in $W / \mathrm{m}^{2}$. This equation relates the three basic environmental variables of wind speed, irradiance and ambient temperature. Two more parameters must be taken into account to normalize the Equation (4) with respect to the free standing case, the mounting effect $(\omega)$ can be defined as $\left(\omega=k_{m t} / k_{f s a}\right)$ Where $k_{m t}$ is the mounting type coefficient and $k_{f s a}$ is the free standing array coefficient. The values for the different types of PV array mounting are listed in Table 1 on the other hand, it is necessary to comment that $v_{f}$ is the wind speed measured by a mast-mounted anemometer above the PV array. It is a better solution to study the effect of local wind speed or wind speed near the PV module $v_{w}$. The transformation from $v_{f}$ to $v_{w}$ be done using the relation

\begin{tabular}{|l|c|}
\hline PV module (array) mounting type & $\boldsymbol{\omega}$ \\
\hline Free standing & 1 \\
\hline Flat roof & 1.2 \\
\hline Sloped roof & $1.8(1-2.7)$ \\
\hline Facade integrated & $2.4(2.2-2.6)$ \\
\hline
\end{tabular}

$\left(v_{f}=v_{w} / 0.67\right)$.

Table 1. Value of Mounting Coefficient $\omega$

Hence, Eq. (4) is written as:

$$
T_{c}=T_{a}+\omega\left[\frac{0.32}{8.91+2 \frac{v_{w}}{0.67}}\right] G
$$

\section{SIMULATION OF PV MODULE MODEL USING MATLAB SIMULINK}

A generalized PV model is built using Matlab/Simulink according to Equations (1),(3) and (5). SOLAR MODULE [130 (17) $\mathrm{P} 1470 \times 680]$ was taken as a reference for simulation input parameters. The proposed model is implemented using Simulink modeling to build the Simulink system according the photovoltaic modelling the subsystems is done in the following:

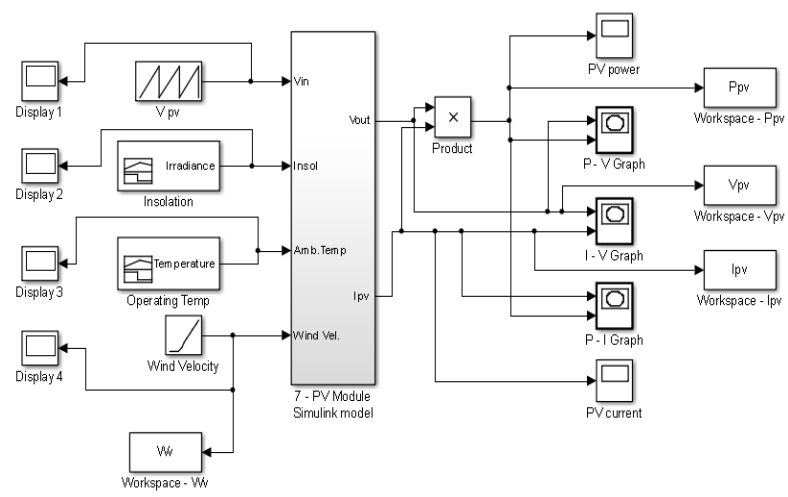

Fig. 2: Simulink Model for PV Module

Figure 2 shows the workspace is added to measure $I_{p v}, V_{p v}$, $P_{p v}, T_{c}, V_{w}$. In this model, the time $t_{o u t}$ is stored in the workspace, the scope model used to plot graph the subsystem include all the 6 subsystems shows in Figure 3.

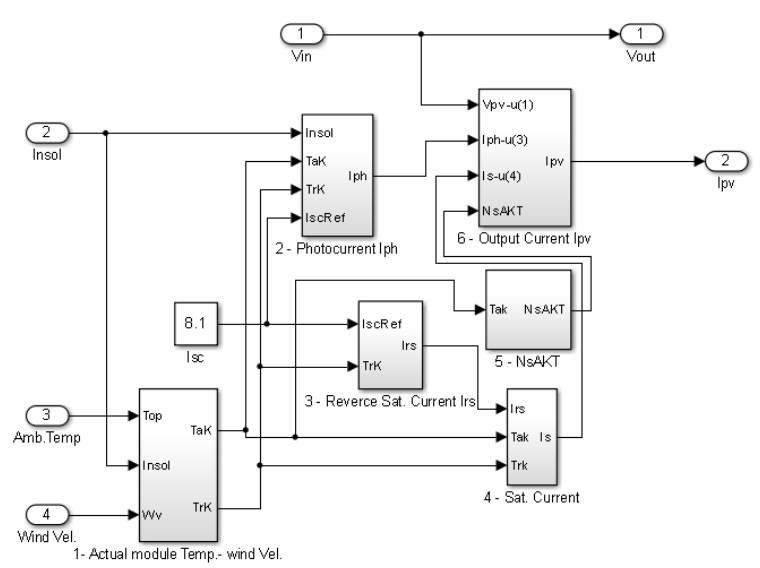

Fig. 3: Interconnection of All Six Subsystems

\section{RESULTS AND DISCUTIONS}

Study of 7 variables variations model will be consider in this paper, the study consist of extracting the Matlab - Simulink results for the variation of Solar Insulation, PV module Temperature, wind speed, Saturation Current $I_{S}$, Ideality Factor $A$, Series Resistance $R_{S}$ and Shunt Resistance $R_{s h}$.

\subsection{Environmental parameter variation 5.1.1. Solar Insulation Variation G:}

Simulink is used in this section to demonstrate behavior of PV module under varying solar insulation at ambient Temperature of $25^{\circ} \mathrm{C}$. The PV Module behavior is more like a current source than a voltage source. 


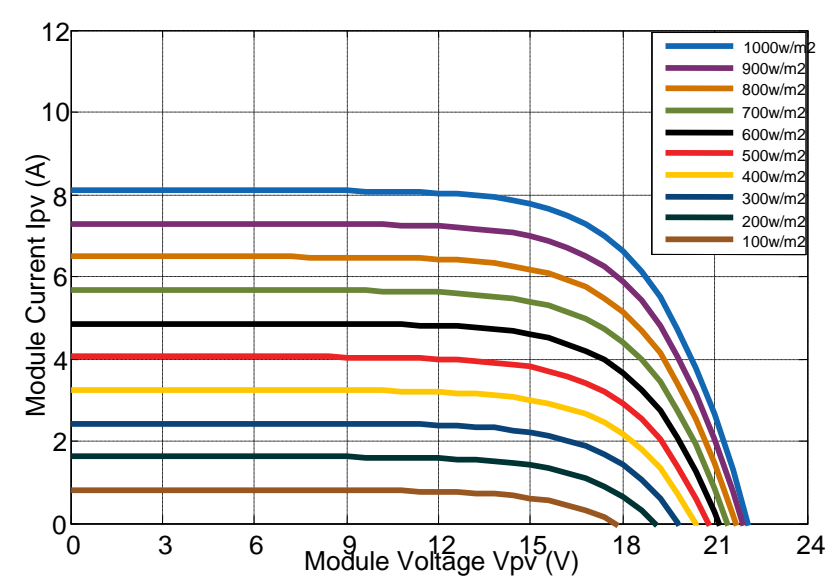

Fig. 4: I-V Graph for PV Module at Variation Irradiation; $100-1000 \mathrm{~W} / \mathrm{m}^{2}$ - Constant Ambient Temperature $25^{\circ} \mathrm{C}$.

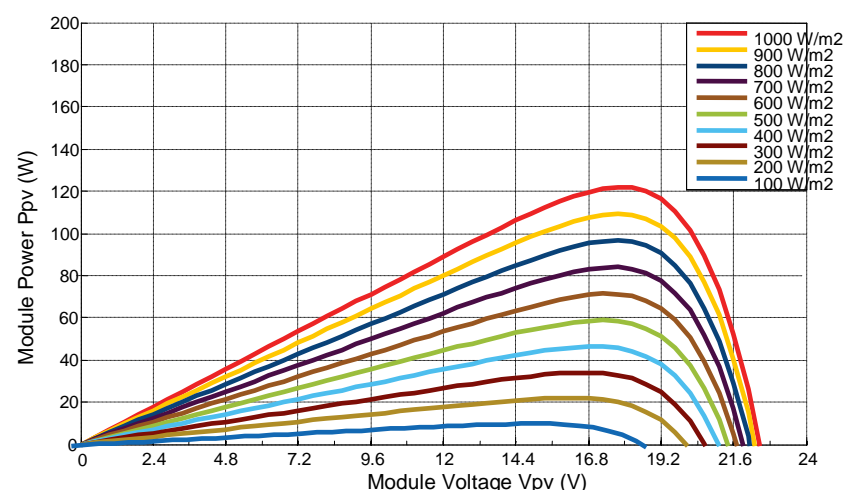

Fig. 5: P-V Graph for PV Module at Variation Irradiation; $100-1000 \mathrm{~W} / \mathrm{m}^{2}$ - Constant Ambient Temperature $25^{\circ} \mathrm{C}$.

\subsubsection{PV Module Temperature Variation} $\mathrm{I}-\mathrm{V}$ and $\mathrm{P}-\mathrm{V}$ characteristics are studied in two different temperatures degrees $25^{\circ} \mathrm{C}$ and $50^{\circ} \mathrm{C}$, at constant Irradiation 1 Sun $1000 \mathrm{~W} / \mathrm{m}^{2}$ and $1 \mathrm{~m} / \mathrm{s}$ wind speed.

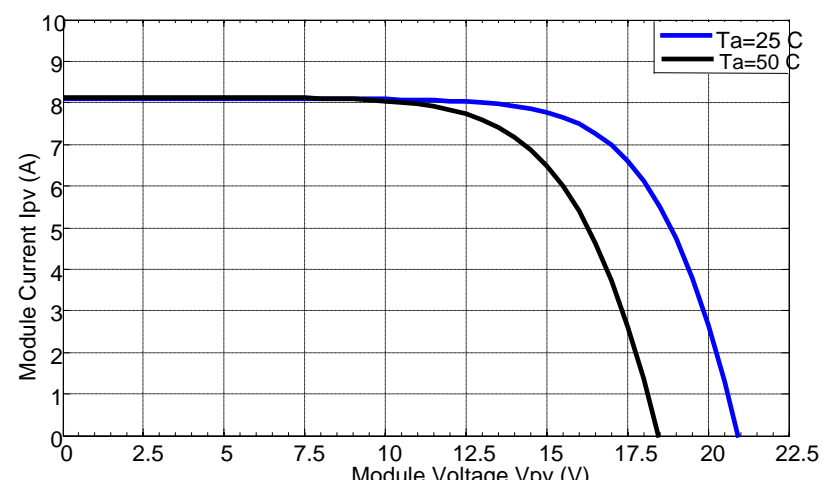

Fig. 6: I-V Graph for PV Module at Constant Irradiation $1000 \mathrm{~W} / \mathrm{m}^{2}$ - Varying Ambient Temp.; $25^{\circ} \mathrm{C}-50{ }^{\circ} \mathrm{C}$.

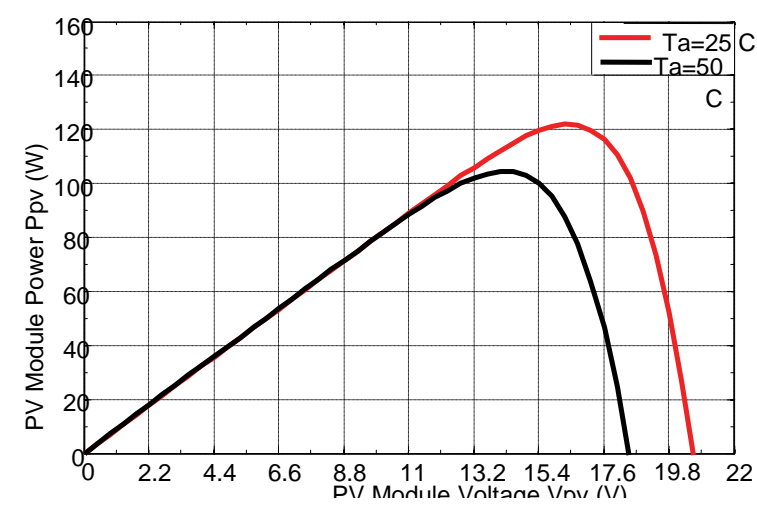

Fig. 7: P-V Graph for PV Module at Constant Irradiation $1000 \mathrm{~W} / \mathrm{m}^{2}$ - Varying Ambient Temp.; $25^{\circ} \mathrm{C}-50{ }^{\circ} \mathrm{C}$.

\subsubsection{Wind Speed Variation}

To study the effect of wind speed on the operating temperature two different simulations are presented at the value range of time $10 \mathrm{~s}$. As expected, the wind speed is in inverse proportion to the PV module operating temperature due to the fact that it increases the heat transfer process in the PV module.

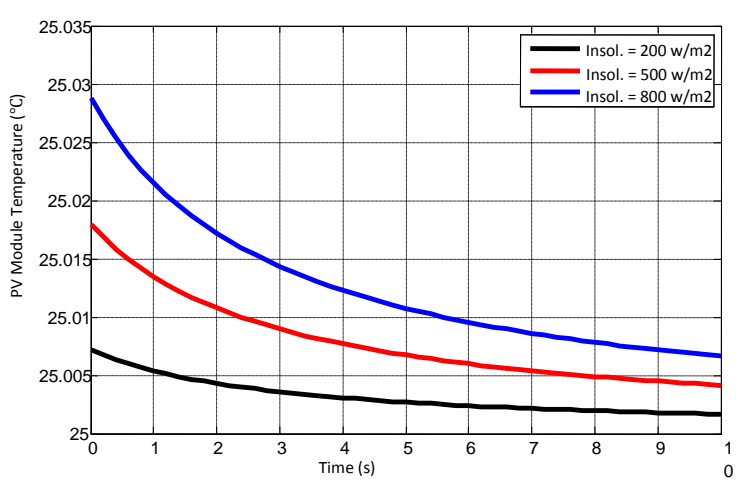

Fig. 8: Wind Speed Effect on PV Module Temperature at Varying Irradiation and Constant Ambient Temperature $25^{\circ} \mathrm{C}$

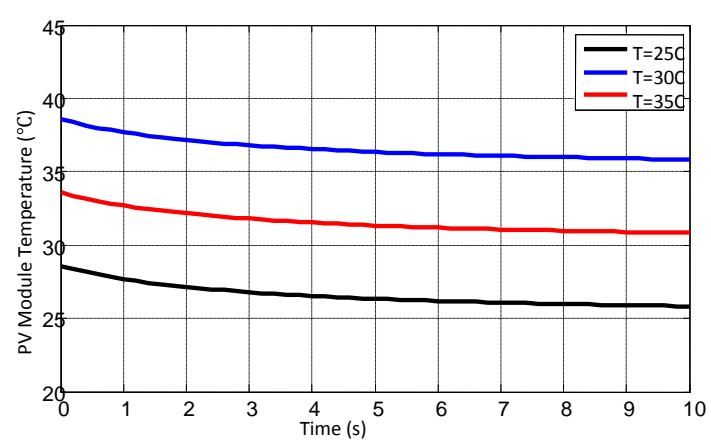

Fig. 9: Wind Speed Effect on PV Module Temperature at Constant Irradiation $1000 \mathrm{~W} / \mathrm{m}^{2}$ and Varying Ambient Temperatures $25^{\circ} \mathrm{C}, 30^{\circ} \mathrm{C}$ and $35^{\circ} \mathrm{C}$. 


\subsection{Essential PV Module Parameter}

\section{Variation}

\subsubsection{Variation of Ideality Factor A}

With slight modifications Simulink model, the I-V and P-V characteristic with changing value of $A$. It can be observed that as we increase value of $A$, the open circuit voltage of module decrease and this fact may effectively be used in simulation of a PV module, which is a congregation of many cells in series.
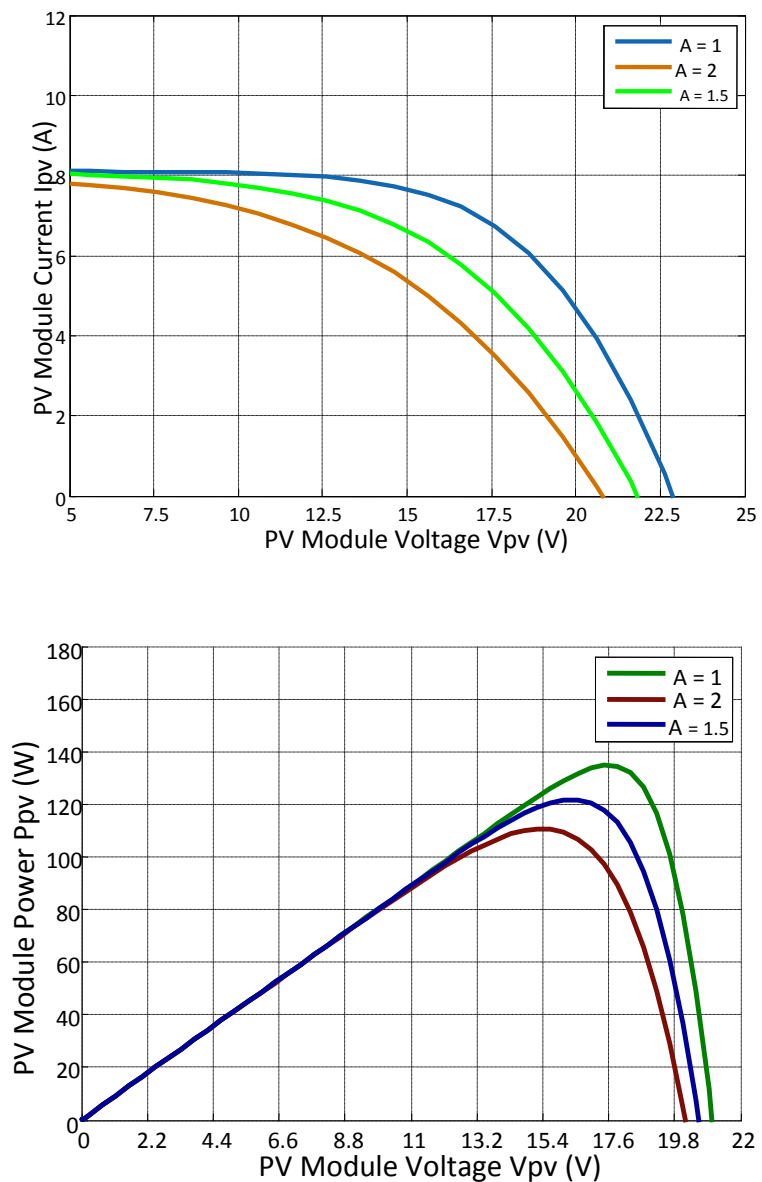

Fig. 10: (I-V) \& (P-V) Graphs for PV Module Ideality Factor (A)

\subsubsection{Variation of Saturation Current $I_{s}$}

Another important model parameter which reflects variation in $\mathrm{I}-\mathrm{V}$ and $\mathrm{P}-\mathrm{V}$ characteristics of PV module which is diode reverse saturation current $I_{S}$.
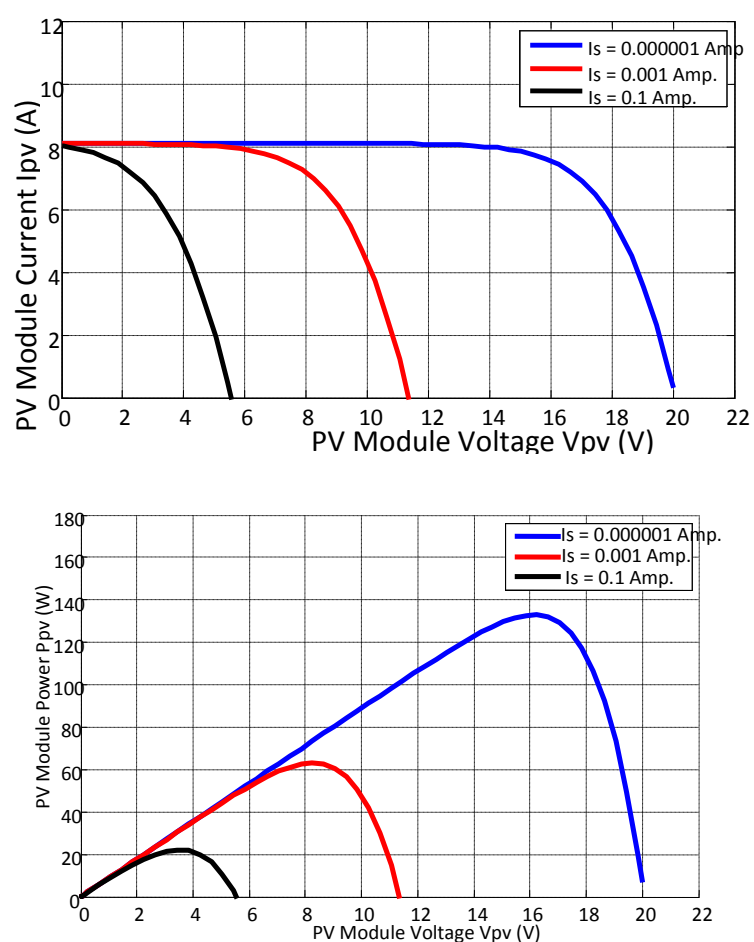

Fig. 11: (I -V) \& (P - V) Graphs Shows the PV Module Saturation Current $I_{s}$ Variation Effect at $1000 \mathrm{~W} / \mathrm{m}^{2}$ Irradiance - Ambient Temperature $25^{\circ} \mathrm{C}$.

\subsubsection{Variation of Series Resistance $\boldsymbol{R}_{S}$} Increasing value of $R_{S}$ can be seen using Simulink model produced.

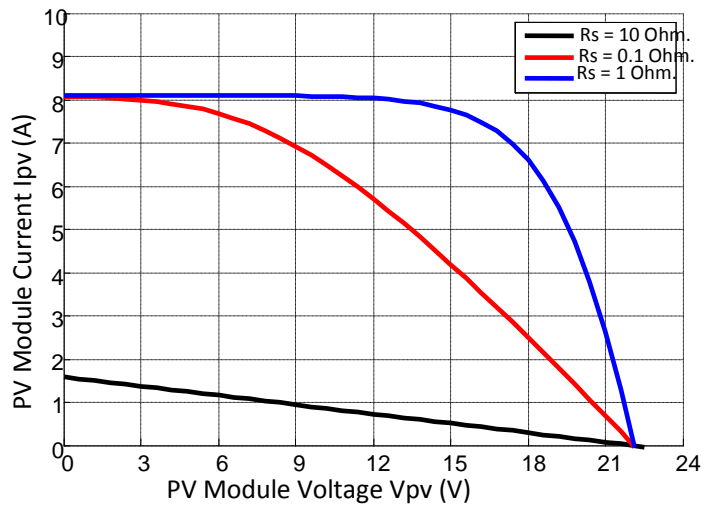




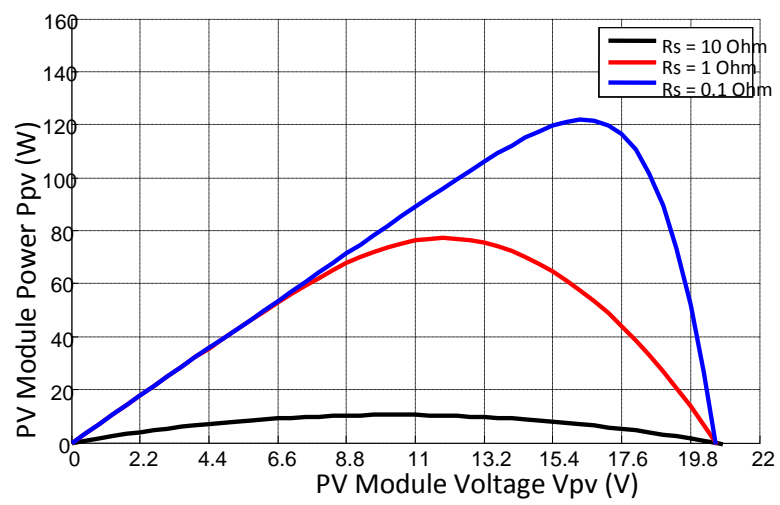

Fig. 12: (I -V) \& $(P-V)$ Graphs Shows the PV Module Series Resistance $R_{s}$ Variation Effect at $1000 \mathrm{~W} / \mathrm{m}^{2}$ Irradiance - Ambient Temperature $25^{\circ} \mathrm{C}$

\subsubsection{Variation of Shunt Resistance $\boldsymbol{R}_{s h}$}
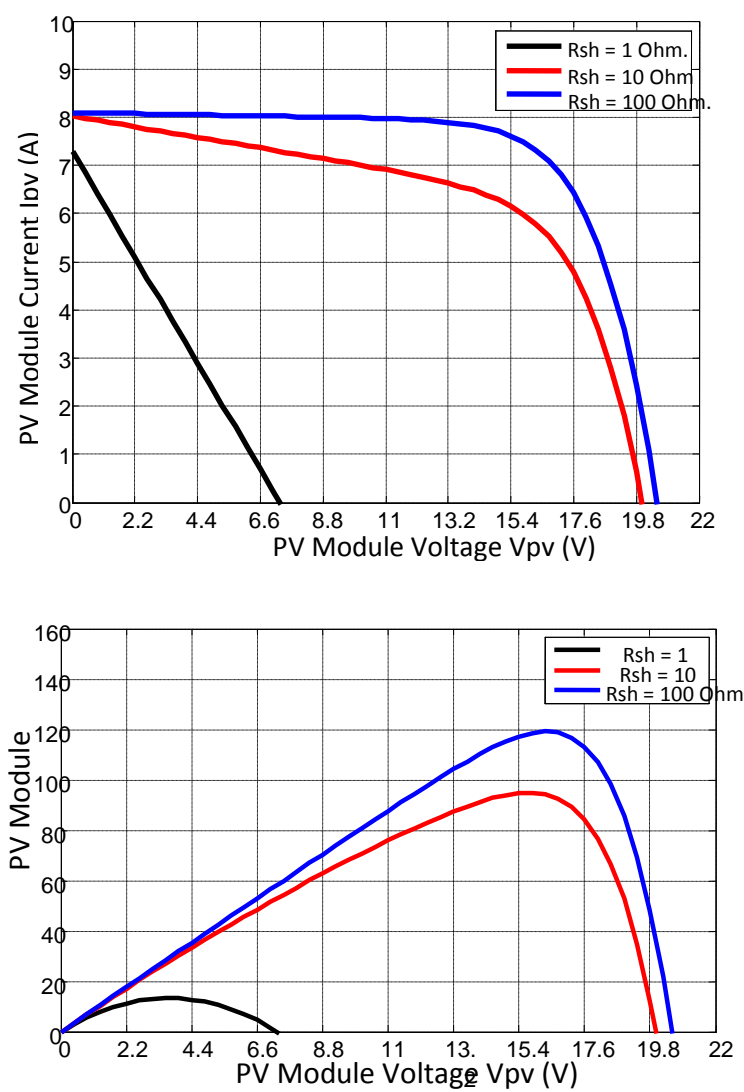

Fig. 13: (I -V) \& (P - V) Graphs Shows the PV Module Shunt Resistance $R_{s h}$ Variation Effect at $1000 \mathrm{~W} / \mathrm{m}^{2}$ Irradiance - Ambient Temperature $25^{\circ} \mathrm{C}$

\section{CONCLUSION}

A Photovoltaic model is easy to be used for the implementation on Matlab - Simulink modeling and simulation platform. Specially, in the context of the Sim Power-System tool, the PV model can be used for the modeling and analysis in the field of solar PV power conversion system. The purpose of using Simulink for simulation is that system study as a whole can be undertaken as it can simulate PV modules under different operating conditions, where The 7 variable studying models successfully reproduce $I_{p v}-V_{p v}$ and $P_{p v}-V_{p v}$ curves and matches real module data under different scenarios. In the proposed model of the PV generator the values $I_{s c}, V_{O C}, I_{M P}, V_{M P}$ can be conveniently inputted, when they are known under specific atmospheric conditions, while the model is also expandable in case of irradiance and temperature variations.

\section{REFERENCES}

[1] Altas I. H. and Sharaf A.M. (2007). A Photovoltaic Array Simulation Model for Matlab-Simulink GUI Environment. IEEE, Clean Electrical Power, International Conference on Clean Electrical Power (ICCEP '07), June 14-16, Ischia, Italy.

[2] Brano, V. L., Orioli, A., Ciulla, G. and Gangi, A. D. (2010). An improved five-parameter model for photovoltaic modules, Solar Energy Materials and Solar $\begin{array}{llll}\text { Cells } & 94(8): & 1358- & 1370 .\end{array}$ 10.1016/j.solmat.2010.04.003

[3] Da Silva R. M. and Fernandes J. L. M. (2010). Hybrid photovoltaic/thermal (PV/T) solar systems simulation with Simulink/Matlab. Solar Energy. 84: 1985-1996.

[4] Duffie, J. A. and W.A. Beckman, (2006). Solar Engineering of Thermal Processes. 3 Edition, John Wiley and Sons Inc.

[5] Liu, S. and Dougal, R. A. (2002). Dynamic multiphysics model for solar array, IEEE Transactions on Energy $\begin{array}{lll}\text { Conversion } & 17(2): & 285-294 .\end{array}$ 10.1109/TEC.2002.1009482.

[6] Nema, R. K., Nema, S. and Agnihotri, G. (2009). Computer simulation based study of photovoltaic cells/modules and their experimental verification, International Journal of Recent Trends in Engineering 1(3): $151-156$.

[7] Shockley, W. and Queisser, H. J. (1961). Detailed balance limit of efficiency of $\mathrm{p}-\mathrm{n}$ junction solar cells, Journal of Applied Physics 32(3): 510-519. DOI: 10.1063/1.1736034.

[8] Skoplaki E., A.G. Boudouvis, J.A. Palyvos: A simple correlation for the operating temperature of photovoltaic modules of arbitrary mounting; Solar Energy Materials \& Solar Cells (2008), pp. 1393-1402.

[9] Villalva, M. G., Gazoli, J. R. and Filho, E. R. (2009a). Comprehensive approach to modeling and simulation of photovoltaic arrays, IEEE Transactions on Power Electronics 24(5): 1198-1208. DOI 10.1109/TPEL.2009.2013862. 